\title{
Farklı Tip Uçucu Küllerin Kauçuğun Mekanik Özelliklerine Etkisinin Deneysel İncelenmesi
}

\author{
Mert Şafak Tunalığlu ${ }^{1 *}$ \\ ${ }^{1}$ Hitit Üniversitesi, Mühendislik Fakültesi, Makina Mühendisliği Bölümü, Çorum, Türkiye (ORCID: 0000-0003-0992-9003)
}

(İlk Geliş Tarihi 15 Ocak 2020 ve Kabul Tarihi 27 Mart 2020)

(DOI: $10.31590 /$ ejosat.675297)

\begin{abstract}
ATIF/REFERENCE: Tunalığlu, M., Ş. (2020). Farklı Tip Uçucu Küllerin Kauçuğun Mekanik Özelliklerine Etkisinin Deneysel İncelenmesi. Avrupa Bilim ve Teknoloji Dergisi, (18), 790-804.
\end{abstract}

\begin{abstract}
Özet
Günümüzün en önemli sorunlarından bir tanesi de atık malzemelerin doğaya zarar vermeden depolanması veya ortadan kaldırılmasıdır. Termik santrallerde kömürün yakılmasıyla atık bir ürün olan uçucu küller ortaya çıkmaktadır. Uçucu küllerin boyutları genellikle 0.5 ile $200 \mu \mathrm{m}$ arasında değişen, camsı yapıya sahip küresel parçacıklardır. Uçucu küller havaya karışıp çevreye zarar vermemesi için çeşitli yollarla toplanırlar. Toplanan uçucu küllerin büyük bir bölümü depolanma yöntemiyle ortadan kaldırılır. Dünyada artan nüfus ile birlikte termik santral kullanımı ve dolayısıyla atık uçucu kül miktarı da artmaktadır. Artan uçucu kül miktarının doğaya zarar vermeden ortadan kaldırılması git gide zorlaşmaktadır. Bu uçucu külleri ortadan kaldırmanın diğer bir yolu da özellikle inşaat ve plastik endüstrisinde ikincil katkı maddesi olarak kullanmaktır. Bu sayede hem uçucu küller kullanıldıkları malzemelere olumlu yönde etki etmekte hem de doğaya zarar vermeden ortadan kaldırılmaktadırlar. Bu amaçla yapılan çalışmada farklı kimyasal özelliklere sahip dört adet uçucu kül SBR(styrene-butadiene rubber) kauçuğa eklenerek, kauçuk üzerindeki mekanik etkileri incelenmiştir. Çalışmada Amerika'nın Teksas Eyaletinde bulunan termik santrallerden Class F, Micron ${ }^{3}$, PV 14A ve PV 20A tipi uçucu küller ikincil katkı maddesi olarak kullanılmıştır. Birincil katkı maddesi olarak karbon siyahı kullanılmıştır. Testlerde birincil katkı maddesi olarak karbon siyahı ve \%5,10,15,20 oranlarında ikincil katkı maddesi olarak uçucu kül kauçuk malzemeye eklenmiştir. Deneylerde birincil katkı maddesi olarak \%100 karbon siyahı eklenerek üretilen kauçuk malzemeler ile farklı oranlarda uçucu kül eklenerek üretilen kauçuk malzemelerin çekme dayanımı ve kopma uzama değerleri karşılaştırılmıştır. Bu şekilde atık ürün olan uçucu küller kullanılarak çevreye olan zararları azaltılmış hem de plastik malzemenin çekme dayanımında ve kopma uzamasında artış sağlandığı gözlenmiştir.
\end{abstract}

Anahtar Kelimeler: Uçucu Kül, Kauçuk, Karbon Siyahı.

\section{Experimental Investigation of the Effects of Different Types of Fly Ashes on Mechanical Properties of Rubber}

\begin{abstract}
One of the most important problems of today is the storage or disposal of waste materials without damaging the nature. Fly ash, a waste product, emerges by burning coal in thermal power plants. Fly ashes are spherical particles with a glassy structure, usually between 0.5 and $200 \mu \mathrm{m}$ in size. Fly ashes are collected in various ways to prevent air pollution and harm to the environment. A large part of the collected fly ash is eliminated by storage. With the increasing population in the world, the use of thermal power plants and therefore the amount of waste fly ash is also increasing. Increasing the amount of fly ash without harming nature is becoming increasingly difficult. Another way to eliminate these fly ashes is to use it as a secondary additive, especially in the construction and plastics industry. In this way, both fly ash has a positive effect on the materials they are used and they are eliminated without damaging the nature. In this study, four fly ashes with different chemical properties were added to SBR (styrene-butadiene rubber) rubber and their mechanical effects on rubber were investigated. In the study, fly ash of Class F, Micron ${ }^{3}$, PV $14 \mathrm{~A}$ and PV $20 \mathrm{~A}$ types of thermal power plants in Texas, USA were used as secondary additive. Carbon black was used as the primary additive. In the tests,
\end{abstract}

* Sorumlu Yazar: Hitit Üniversitesi, Mühendislik Fakültesi, Makina Mühendisliği Bölümü, Çorum, Türkiye, ORCID: 0000-0003-0992-9003, $\underline{\text { mstunalioglu@gmail.com }}$ 
carbon black as the primary additive and fly ash as the secondary additive at 5,10,15,20\% were added to the rubber material. In the experiments, tensile strength and elongation values of rubber materials produced by adding $100 \%$ carbon black as primary additives and rubber materials produced by adding different amounts of fly ash were compared. In this way, it is observed that the waste products fly ash is reduced to environmental damage and also the increase in tensile strength and elongation of the plastic material is observed.

Keywords: Fly ash, Rubber, Carbon black.

\section{Giriş}

Uçucu kül, kömürün tek başına termik santrallerde yakılması sonucu ortaya çıkan bir üründür. Uçucu küllerin çevreyi olumsuz etkilememesi için mekanik ve elektrostatik yöntemlerle toplanarak havaya karışması önlenir. Termik santrallerde kullanılan taşkömürünün \%10-15'i, linyit kömürünün ise \%20-50'si kül olarak ortaya çıkmaktadır (Morrison, 1970). Uçucu küller; uçucu külün kaynağını oluşturan kömürün türüne ve değişkenliğine, kömürün yakılmadan önce öğütülme (pulvarizasyon) derecesine, kazan tipine, yakma sıcaklığına, kül toplama ve uzaklaştırma sistemlerinin özelliklerine ve işleyişi gibi özelliklere göre değişiklik gösterirler (Güler vd., 2005). Uçucu kül, koyu gri renkte, çok ufak taneli bir malzemedir (Şekil 1). Renginin koyuluğu veya açıklığı, elde edildiği kömüre ve yanış özelliğine bağlıdır. Uçucu külün inceliği öncelikle kazana verilen kömürün öğütülme derecesine bağlıdır (Morrison, 1970).

Uçucu küllerin boyutları genellikle 0.5 ile $200 \mu \mathrm{m}$ arasında değişir. Camsı yapıya sahip çoğunlukla küresel karakterdeki parçacıklardır (Şekil 1). Spesifik yüzeyleri $1800-5000 \mathrm{~cm} / \mathrm{gr}$ arasında değişmekle birlikte, ortalama $2800-3800 \mathrm{~cm}^{2} / \mathrm{gr}$ dolayındadir (Morrison, 1970).

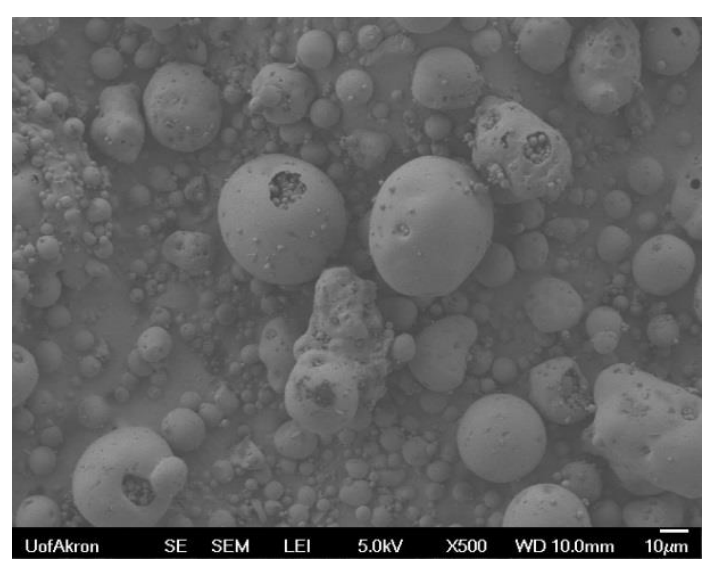

(a)

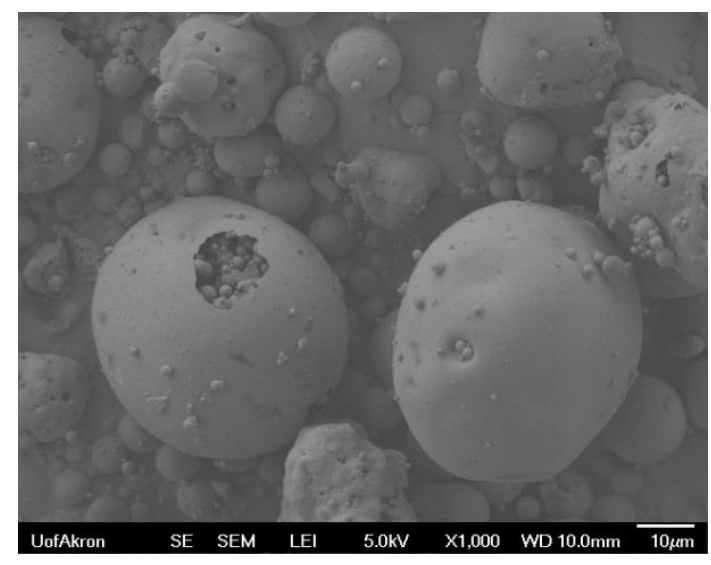

(b)



(c)

Şekil 1. Uçucu küllerin SEM fotoğrafları (a,b,c sırası ile X500, X1000, X1500 büyüklükleridir).

Uçucu küllerin kimyasal kompozisyonları incelendiği zaman $\mathrm{SiO}_{2}, \mathrm{Al}_{2} \mathrm{O}_{3}, \mathrm{CaO}, \mathrm{Fe}_{2} \mathrm{O}_{3}$ ve $\mathrm{MgO}$ 'in yer aldığ bileşiklerden olduğu gözükmektedir. İçerisinde bulunabilen karbon miktarı kömür tipine ve yakma işlemine göre değişiklikler göstermektedir (Morrison, 1970). Uçucu küllerin matrisi esas olarak alümina silikatlardan ve bunlarla birlikte bulunabilen Fe, Mg, Na, K, Ca, Ti ve nadir toprak elementlerinden oluşur. Uçucu olan veya uçucu oksitleri oluşturan As, $\mathrm{Cd}$, Ga, Mo, Pb, Se ve Zn gibi elementler matrise girme eğilimi göstermezler. Bu elementler derişimleri tane boyutu ile ters orantılı olarak uçucu küllerin yüzeylerinde toplanırlar (Morrison, 1970).

Uçucu kül üzerinde yapılan araştırmalar son 25-30 yılda büyük yoğunluk kazanmıştır. Önceden daha çok uçucu külün genel yapısı ve özellikleri ile kullanım olanaklarına yönelen çalışmalar, zamanla laboratuvar ve arazide geçekleşen analizlerle geliştirilmiş, 
sonuçta uçucu külün inşaat alanında, özellikle yol yapımında kullanılmasııın, termik santrallerde büyük mertebelerde atık madde olarak oluşan bu malzemenin uzaklaştırılması sorununa çözüm getireceği açığa kavuşmuştur (Güler vd., 2005).

Ülkemizde bu konuda Türk Standartları Enstitüsü tarafından TS-639 'Uçucu Küller' ve TS 640 'Uçucu Küllü Çimento' standartları çıkarılmıştır. Uçucu küller dünyada çimento ve beton olarak baraj duvarları köprü ayakları, maden ve diğer yapıların dolgu enjeksiyonlarında ve diğer pek çok inşaat yapılarında, tarımda çatı bahçesi ve ağaçlandırma çalışmalarında, otoyol, köprü, yol ve briket yapımında ve asfalt içinde dolgu maddesi olarak kullanılmaktadır (Güler vd., 2005).

Gerek ülkemizde gerekse diğer ülkelerde uçucu kül ile ilgili birçok çalışma yapılmıştır. Bu çalışmalar ilk zamanlar uçucu küllerin çimentoya katkı maddesi olarak eklenmesi ile başlamış olup daha sonra kauçuğa eklenmesiyle ağırlık kazanmıştır.

Uçucu küllerin geoteknik özellikleri ve kullanım alanları ile ilgili yapılan çalışmalarda (Wasti, 1990; Elverici, 1986; Büyüköner, 1989; Savran, 1988; Uysal, 1987), uçucu maddelerin özellikleri ve inşaat sektöründe, yapı ve yol malzemesine eklenmesi anlatılmıştır.

Uçucu küllerin kullanım alanları ve özelliklerinden sonra, Türkiye'de Afşsin Elbistan ve Seyitömer gibi Termik santrallerde kömürün yanması sonucu oluşan uçucu küllerin özellikleri ve yapı malzemesi olarak kullanım özellikleri incelenmiştir (Alataş, 1996; Ergüt, 1994; Toros, 1987; Yılmaz, 1982; Hamamc1, 1991).

Uçucu küller polimer esaslı malzemelerde mekanik özellikleri geliştirmek için birincil veya ikincil katkı malzemesi olarak kullanılmışlardır. Ooi ve diğerleri (Ooi vd., 2013); palmiye ağacının külünü doğal kauçuk ile 0-9 phr oranlarında karıştırarak külün kauçuktaki kürleşme sıcaklığına, mekanik özelliklere ve kauçuğun yüzeyine etkilerini incelemişlerdir. Palmiye ağacı külünün kauçuk içerisindeki miktarı arttıkça kürleşme sıcaklık süresinin düştüğünü, çekme modülünün ve sertliğin arttığını belirlemişlerdir. Kanking ve diğerleri (Kanking vd., 2012); şeker kamışı külünü doğal kauçuğa ikincil katkı maddesi olarak ekleyip kauçuğun kürleşme karakteristikleri ve mekanik özelliklerini incelemişlerdir. Doğal kauçuğa birincil katkı maddesi olarak çökelmişs silika (PSi) ve karbon siyahı (CB) eklenmiştir. Şeker kamışı külünün ikincil katkı maddesi olarak kullanılmasının en büyük nedeni içeriğinde \%75.4 oranında $\mathrm{SiO}_{2}$ bulunmasıdır. Şeker kamışı külü doğal kauçuğa 0-15-30-45 oranlarında eklenmiştir. Şeker kamışı külü \%15'e kadar mekanik özelliklerde bir değişme göstermemiş, \%15-25 arası mekanik özellikleri iyileştirmiştir. Cokca ve diğerleri (Cokca ve Yilmaz, 2004); Soma'da (Türkiye) üretilen C tipi uçucu küle değişik oranlarda birincil katkı maddesi olarak bentonit, ikincil katkı maddesi olarak doğal kauçuk eklemişlerdir. Karışım oranları $\% 90 \mathrm{C}$ tipi uçucu kül, \%0-10 bentonit ve \%0-10 doğal kauçuk şeklindedir. Sonuçlar yapılar için C tipi uçucu küller iyi sonuçlar vermektedir. Ray (Ray, 2009); SBR (styrene-butadiene rubber) kauçuğa uçucu külü ikincil katkı maddesi ekleyip, kauçuğun mekanik özelliklerini incelemiştir. Karışım \%1-10 SBR, \%40-50 oranında uçucu kül ve \%40-50 arasında doymamış polyester reçine şeklindedir. En iyi sonuçlar \%20-30 arası uçucu kül eklenmesiyle görülmüştür. Rattanasom ve diğerleri (Rattanasom vd., 2007); doğal kauçuğa silika/karbon siyahı şeklinde hibrid katkıları eklemiştir. Deneysel çalışmalar sonucunda 20-30 phr arası silikanın daha iyi mekanik özellik gösterdiğini belirlemişlerdir. Bahruddin ve diğerleri (Bahruddin vd., 2012); doğal kauçuğa birincil katkı maddesi olarak polipropilen (PP) ve ikincil katkı maddesi olarak palmiye ağacı uçucu külü (PFA) eklemiştir. Kauçuk PP oranı 70/30 şeklinde ve 5-50 phr arası uçucu kül eklenmiştir. Karışıma bunun yanı sıra 5 phr $\mathrm{ZnO}, 2 \mathrm{phr}$ stearik asit, $0.6 \mathrm{phr}$ mekaptodibenzotiozildisülfit ve $3 \mathrm{phr}$ sülfür eklenmiştir. PFA çekme kuvvetini iyi yönde arttırmakta, homojenliği sağlamakta ve su emme oranını arttırmaktadır. Van der Merwe ve diğerleri (Van der Merwe vd., 2014); Güney Afrika kömürü uçucu külünü (F tipi) değişik oranlarda katkı maddesi olarak doğal kauçuğa ekleyip SEM (Scanning Electron Microscopy), TEM (Transmission Electron Microscopy) ve AFM (Atomic Force Microscopy) analizleri yapmışlardır. Analizlerinin sonucunda mekanik özelliklerin arttığını gözlemlemişlerdir. Paul ve diğerleri (Paul vd., 2009); nano yapılı uçucu küller ve SBR kauçuk ile nano kompozit yapmışlardır. SBR kauçuğa saf uçucu kül (FFA), nano uçucu kül (NFA), karbon siyahı (CB) çökelmişs silika ve Si-69 katkı maddelerini 1,2,4,8,16 phr olarak ekleyerek mekanik özelliklerin değişimi incelenmiştir. Kauçuğa katılan NFA CB'ye göre daha yüksek gerilme özelliklerine sahiptir. Ayrıca NFA partikülleri SBR matris içinde daha iyi yayılmışlardır. Sombatsompop ve diğerleri (Sombatsompop vd., 2004); işlem görmemiş çökelti silika (PSi) ve uçucu külü (FASi) birincil ve ikincil katkı maddesi olarak doğal ve stiren bütadien tipi kauçuğa eklenerek kürleşme sıcaklığı ve mekanik özellikler incelenmiştir. Katkı maddelerini 0-30 phr arası eklenmiş, bu oranlarda doğal kauçukta iyi SBR'da düşük mekaniksel özelliklere sahip olduğu belirlenmişlerdir. Garde ve diğerleri (Garde vd., 1999); uçucu külü katkı maddesi olarak kauçuğa eklemeden önce yaşlandırma işlemine tabi tutulmuş ve bu işlemin mekanik özellikleri \%30 oranında iyileştirdiği görülmüştür. Feldman ve diğerleri (Feldman, 2012); doğal kauçuğa katk1 maddesi olarak değişik miktarlarda karbon siyahı, toz silika parçaları, selülozik kristaller, nano katkı karışımları ve elastomer nano kompozitleri eklemişler, mekanik özellikleri en iyi silika tozlarının arttırdığını belirlemişlerdir.

Bu çalışmada farklı kimyasal özelliklere sahip 4 adet uçucu kül (Class F, Micron³, PV 14A, PV 20A) ikincil katkı maddesi ve karbon siyahı birincil katkı maddesi olarak farklı oranlarda $(\% 0,5,10,15,20)$ SBR(styrene-butadiene rubber) kauçuğa eklenerek, kauçuk üzerindeki mekanik etkileri incelenmiştir.

\section{Materyal ve Metot}

Bu çalışmada farklı kimyasal özelliklere sahip dört adet uçucu kül farklı oranlarda ikincil katkı maddesi olarak kauçuk ile karıştııılarak, uçucu küllerin polimer esaslı malzemelerde etkileri incelenmiştir. Birincil katkı maddesi olarak karbon siyahı kullanılmıştır. Kullanılan uçucu küller 'Boral Material Technologies Inc. Texas, U.S.' tarafindan temin edilmiştir. Uçucu küllerin kimyasal özellikleri Tablo 1'de ayrıntılı olarak verilmiştir. 
Tablo 1. Uçucu küllerin kimyasal özellikleri (BORAL, 2019).

\begin{tabular}{l|l|l|l|l|l}
\hline \multicolumn{1}{c|}{ Bileșenler } & \multicolumn{1}{|c|}{ Formül } & \multicolumn{1}{c|}{$\begin{array}{c}\text { PV 14 A } \\
\text { \% }\end{array}$} & \multicolumn{1}{c|}{$\begin{array}{c}\text { PV 20 A } \\
\text { \% }\end{array}$} & \multicolumn{1}{c}{$\begin{array}{c}\text { Micron } \\
\text { \% }\end{array}$} & \multicolumn{1}{c}{$\begin{array}{c}\text { Class F } \\
\text { \% }\end{array}$} \\
\hline Silika & $\mathrm{SiO}_{2}$ & $<30-40$ & $<20-30$ & $<30-40$ & $<20-25$ \\
\hline Alüminyum oksit & $\mathrm{Al}_{2} \mathrm{O}_{3}$ & $17-21$ & $12-21$ & $21-27$ & $22-29$ \\
\hline Kalsiyum oksit & $\mathrm{CaO}$ & $13-18$ & $13-18$ & $8-11$ & $1-14$ \\
\hline Kuarts (silika) & $\mathrm{SiO}_{2}$ & $<17$ & $<10$ & $<17$ & $<17$ \\
\hline Demir oksit & $\mathrm{Fe}_{2} \mathrm{O}_{3}$ & $4-6$ & $4-6$ & $4-6$ & $5-9$ \\
\hline $\begin{array}{l}\text { Solunabilir silika } \\
\text { kristalleri }\end{array}$ & $\mathrm{SiO}_{2}$ & $<4$ & $<2$ & $<4$ & $<4$ \\
\hline Karbon & $\mathrm{C}$ & 1 & $<1$ & $<1$ & $<6$ \\
\hline
\end{tabular}

Çalışmada kullanılan uçucu küllerin tane boyutları 12 ile $70 \mu \mathrm{m}$ arasında değişmektedir. Şekil 2'de PV 14A'ya ait uçucu küllerin tane boyutu değişimi grafiği verilmektedir.

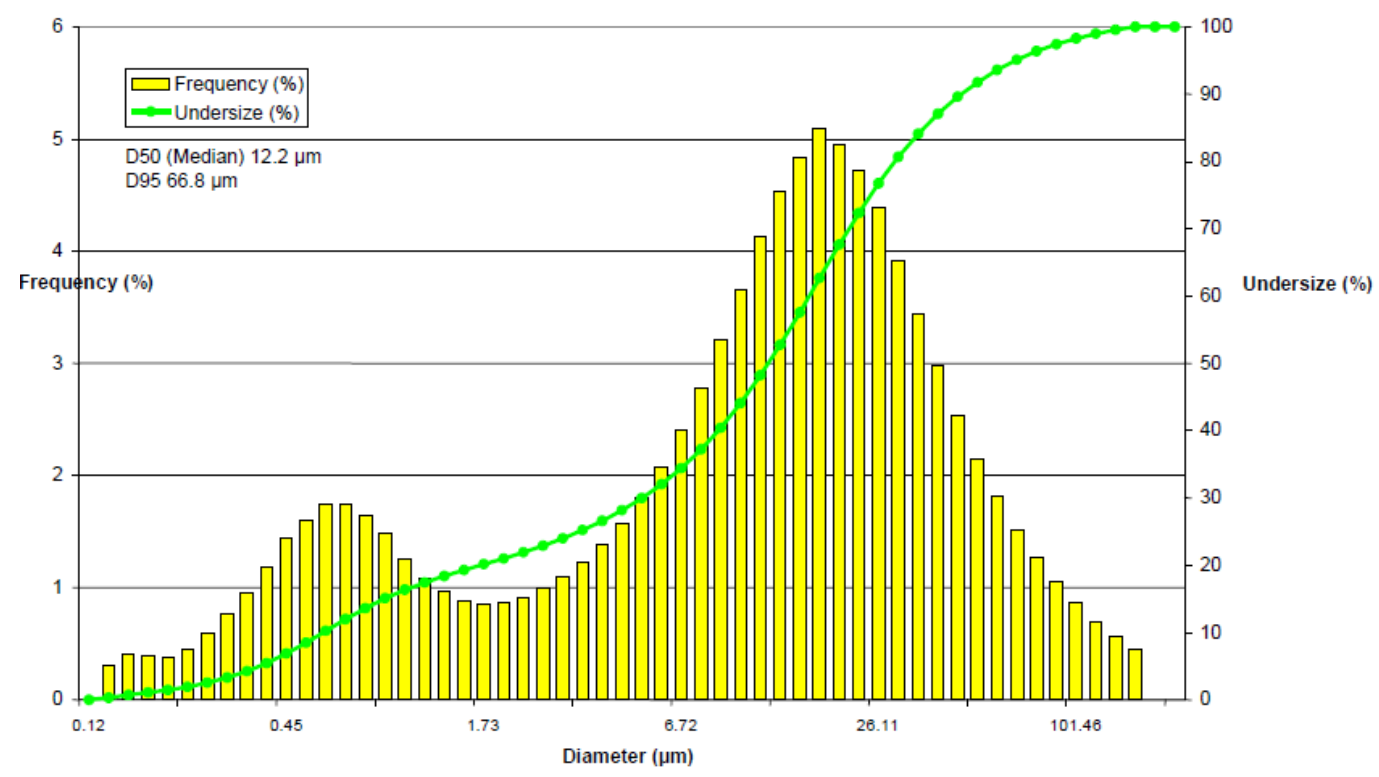

Şekil 2. PV 14A tip uçucu külün tane boyutu (BORAL, 2019).

Deneylerde polimer tipi malzeme olarak Buna VSL 5025-2 HM tipi kauçuk kullanılmıştır. Deneylerde kullanılan kauçuk 'LANXESS Deutschland GmbH, Business Unit PBR Global, Germany' (LANXESS, 2019) tarafından temin edilmiştir. Bu çalışmada kullanılan kauçuğun malzeme özellikleri Tablo 2'de verilmiştir.

Tablo 2. Çalışmada kullanılan kauçuğun malzeme özellikleri (LANXESS, 2019).

\begin{tabular}{l|l|l|l}
\hline Özellik & Nominal Değer & Birim & Test Metodu \\
\hline Uçucu madde & max. 0.75 & $\%$ & MO AQ 255 LAB \\
\hline Mooney viskozitesi & 62 & ME & ASTM D 1646 \\
\hline Vinil bileşen & 50 & $\%$ & MO AQ 254 LAB \\
\hline Stiren bileşen & 25 & $\%$ & MO AQ 243 LAB(UV) \\
\hline Yağ bileşen & 27.3 & $\%$ & MO AQ 246 LAB \\
\hline
\end{tabular}

\subsection{Mikser Cihazı (Brabender) ile Karıştırma}

4 farklı uçucu kül ikincil katkı maddesi olarak, 4 değişik oranlarda (Tablo 3) karbon siyahı birincil katkı maddesi olarak, SBR (Styrene Butadiene Rubber) ve diğer kimyasallar (Tablo 4) ile $90{ }^{\circ} \mathrm{C}$ 'de 15 dakika Brabender Cihazında karıştırılmışır. Cihaz $90{ }^{\circ} \mathrm{C}$ sıcaklığa ulaştığında karışım için sırasıyla SBR, karbon siyahı ve PPD 30 dev/dak hızda 15 dakika karıştırılmıştır. Karışım soğuması için 30 dakika soğutucuda bekletilmiştir. Diğer kimyasalların eklenmesi için karışım soğutucudan alınmış ve $90{ }^{\circ} \mathrm{C}$ sıcaklıkta $\mathrm{ZnO}$, $\mathrm{CBS}$, sülfür ve $\mathrm{CH}_{3}\left(\mathrm{CH}_{2}\right)_{16} \mathrm{CO}_{2} \mathrm{H}$ eklenerek soğuması için soğutucuya konulmuştur. 
Avrupa Bilim ve Teknoloji Dergisi

Tablo 3. Uçucu kül karışım oranları

\begin{tabular}{|c|c|c|c|}
\hline Deney No & Uçucu Kül Adı & $\begin{array}{ll}\text { Uçucu } \\
\text { Oranı }\end{array}$ & $\begin{array}{l}\text { Karbon Siyahı } \\
\text { Oranı }\end{array}$ \\
\hline 1 & Class F & $\% 5$ & $\% 95$ \\
\hline 2 & Class F & $\% 10$ & $\% 90$ \\
\hline 3 & Class F & $\% 15$ & $\% 85$ \\
\hline 4 & Class F & $\% 20$ & $\% 80$ \\
\hline 5 & Micron $^{3}$ & $\% 5$ & $\% 95$ \\
\hline 6 & Micron $^{3}$ & $\% 10$ & $\% 90$ \\
\hline 7 & Micron ${ }^{3}$ & $\% 15$ & $\% 85$ \\
\hline 8 & Micron $^{3}$ & $\% 20$ & $\% 80$ \\
\hline 9 & PV 14A & $\% 5$ & $\% 95$ \\
\hline 10 & PV 14A & $\% 10$ & $\% 90$ \\
\hline 11 & PV 14A & $\% 15$ & $\% 85$ \\
\hline 12 & PV 14A & $\% 20$ & $\% 80$ \\
\hline 13 & PV 20A & $\% 5$ & $\% 95$ \\
\hline 14 & PV 20A & $\% 10$ & $\% 90$ \\
\hline 15 & PV 20A & $\% 15$ & $\% 85$ \\
\hline 16 & PV 20A & $\% 20$ & $\% 80$ \\
\hline
\end{tabular}

Tablo 4. Karışım oranları

\begin{tabular}{l|l|l|l|l}
\hline Görevi & Adı & Phr & $\begin{array}{l}\text { Yoğunluk } \\
\left(\mathbf{g} / \mathbf{c m}^{3}\right)\end{array}$ & $\begin{array}{l}\text { Ăğrlık } \\
(\mathbf{g})\end{array}$ \\
\hline Kauçuk & Buna VSL 5025-2 HM & 100 & 0.93 & 188.68 \\
\hline Katk1 maddesi & Carbon Black N234 & 50 & $1.7-1.9$ & 94.34 \\
\hline Aktivatör & ZnO & 3 & 5.6 & 5.66 \\
\hline Hızlandırıc1 & $\mathrm{CBS}$ & 1.6 & $1.31-1.34$ & 3.02 \\
\hline Kürleştirici & Sülfür & 1.4 & 2.07 & 2.64 \\
\hline Hızlandırıc1 & $\mathrm{CH}_{3}\left(\mathrm{CH}_{2}\right)_{16} \mathrm{CO}_{2} \mathrm{H}$ & 2 & 0.85 & 3.77 \\
\hline $\begin{array}{l}\text { Antioksidant } \\
\text { ve Antiozonant }\end{array}$ & 6-PPD & 1 & 1.02 & 1.89 \\
\hline & & 159 & 1.131 & 300.00 \\
\hline
\end{tabular}

\subsection{Cift Merdaneli Hadde (Two-Roll Mill)}

Mikser cihazından alınan numuneler kalıplama öncesinde çift merdaneli hadde makinasında 25 dakika haddelenmiştir. Şekil 3 'te mikserleme ve çift merdaneli hadde cihazında haddelenen örnek numunelerin fotoğrafları görülmektedir.

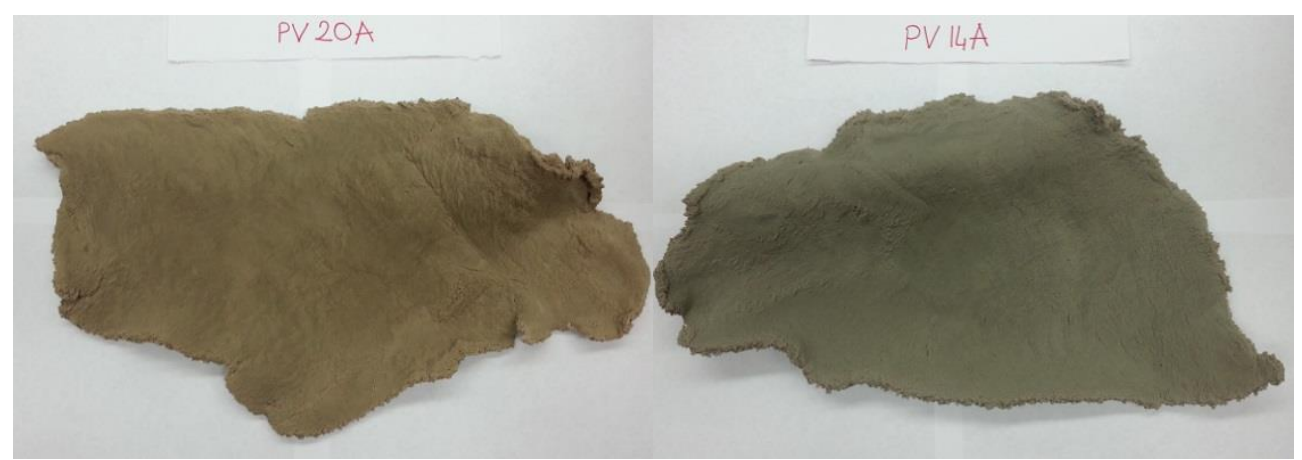




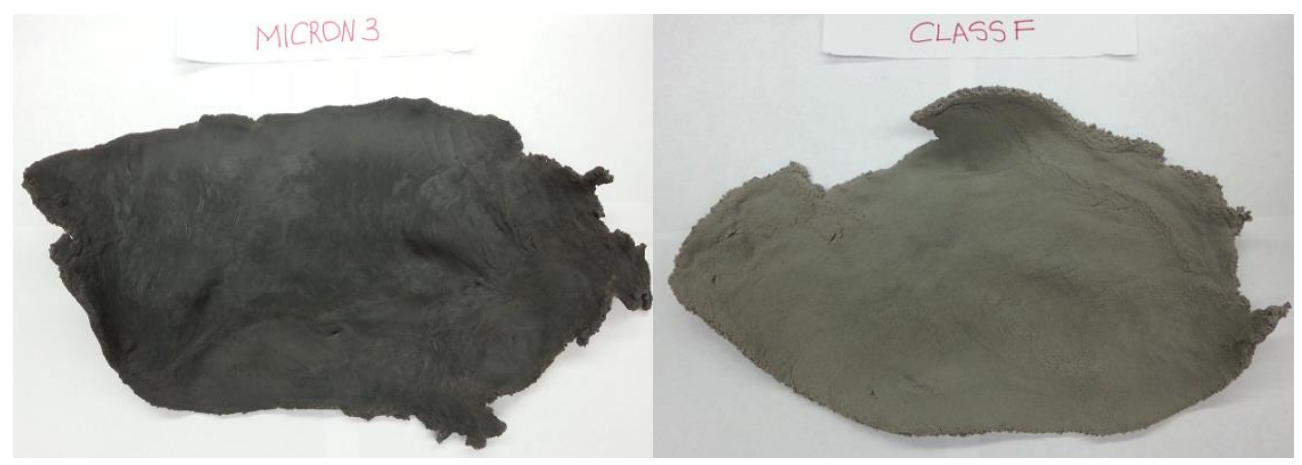

Şekil 3. Mikserleme ve çift merdaneli hadde sonrası numunelerin fotoğraflart.

\subsection{DSC (Differential Scanning Calorimetry)}

DSC cihazı ile numunelerin kürleşme süreleri belirlenmiştir. Numunelerin kürleşme sıcaklıkları ve süreleri Şekil 4 ve Tablo 5 'te verilmiştir. Deneylerde her bir numune $160^{\circ} \mathrm{C}$ 'de 40 dakika DSC cihazında bekletilerek kürleşme süresi belirlenmiştir.

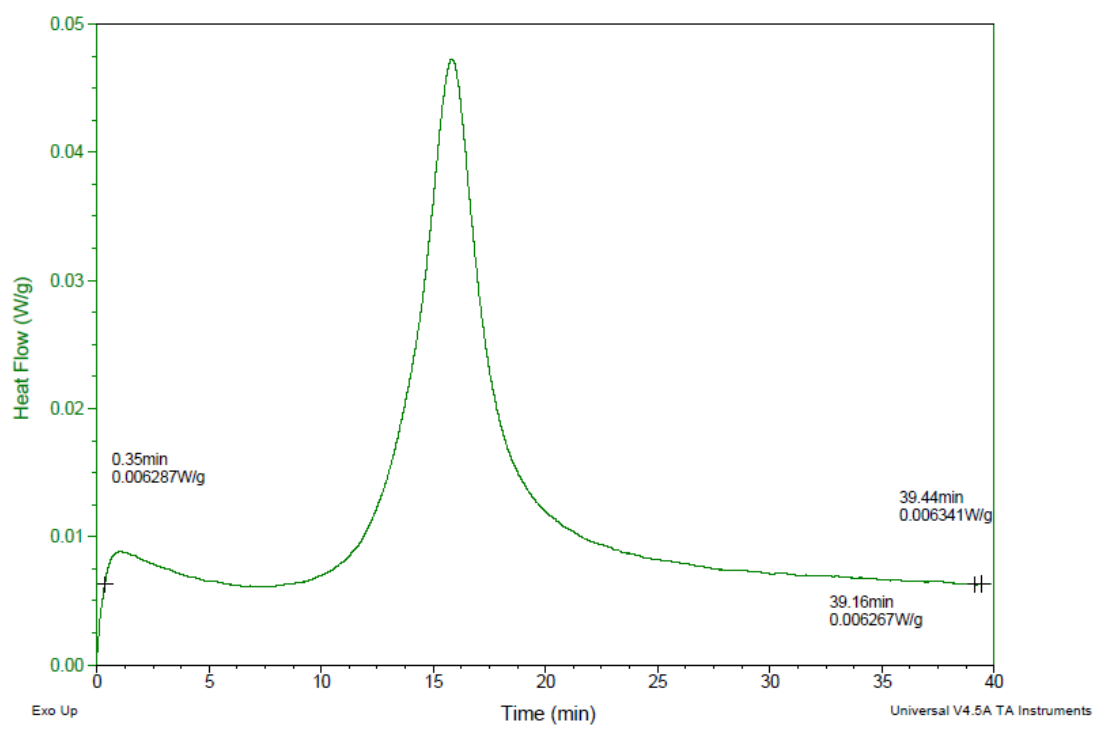

Şekil 4. Örnek DSC grafiği

Tablo 5. Kürleşme sıcaklıkları

\begin{tabular}{|c|c|c|c|c|c|}
\hline $\begin{array}{l}\text { Deney } \\
\text { No }\end{array}$ & Uçucu Kül Adı & $\begin{array}{l}\text { Uçucu Kül } \\
\text { Oranı }\end{array}$ & $\begin{array}{l}\text { Karbon } \\
\text { Oran1 }\end{array}$ & $\begin{array}{l}\text { Kürleşme } \\
\text { Sicaklığ } 1\left({ }^{\circ} \mathrm{C}\right)\end{array}$ & $\begin{array}{l}\text { Kürleşme } \\
\text { Zamanı (s.) }\end{array}$ \\
\hline 1 & Class F & $\% 5$ & $\% 95$ & 160 & 18 \\
\hline 2 & Class F & $\% 10$ & $\% 90$ & 160 & 18.4 \\
\hline 3 & Class F & $\% 15$ & $\% 85$ & 160 & 19 \\
\hline 4 & Class F & $\% 20$ & $\% 80$ & 160 & 19.5 \\
\hline 5 & Micron $^{3}$ & $\% 5$ & $\% 95$ & 160 & 18 \\
\hline 6 & Micron $^{3}$ & $\% 10$ & $\% 90$ & 160 & 19 \\
\hline 7 & Micron $^{3}$ & $\% 15$ & $\% 85$ & 160 & 19.2 \\
\hline 8 & Micron $^{3}$ & $\% 20$ & $\% 80$ & 160 & 19.4 \\
\hline 9 & PV 14A & $\% 5$ & $\% 95$ & 160 & 18 \\
\hline 10 & PV 14A & $\% 10$ & $\% 90$ & 160 & 18.5 \\
\hline 11 & PV 14A & $\% 15$ & $\% 85$ & 160 & 18.5 \\
\hline 12 & PV 14A & $\% 20$ & $\% 80$ & 160 & 19 \\
\hline 13 & PV 20A & $\% 5$ & $\% 95$ & 160 & 18.2 \\
\hline 14 & PV 20A & $\% 10$ & $\% 90$ & 160 & 18.2 \\
\hline 15 & PV 20A & $\% 15$ & $\% 85$ & 160 & 18.8 \\
\hline 16 & PV 20A & $\% 20$ & $\% 80$ & 160 & 19.1 \\
\hline 17 & Karbon Siyahı & $\% 0$ & $\% 100$ & 160 & 18.5 \\
\hline
\end{tabular}




\subsection{Kürleşme Cihazı:}

Deney numuneleri DSC cihazı ile elde edilen kürleşme süreleri ve sıcaklıklarına uygun olarak kürleşme kalıbıyla birlikte kürleştirilme işlemine tabi tutulmuştur. Her bir numune kendine özgü sıcaklıkta kürleştirildikten sonra çekme deneyleri için kesme işlemi yapılmıştır. Deneylerde kullanılacak numuneler ASTM D4482 standartlarına uygun olarak üretilmiştir (Liu ve Sancaktar, 2018).

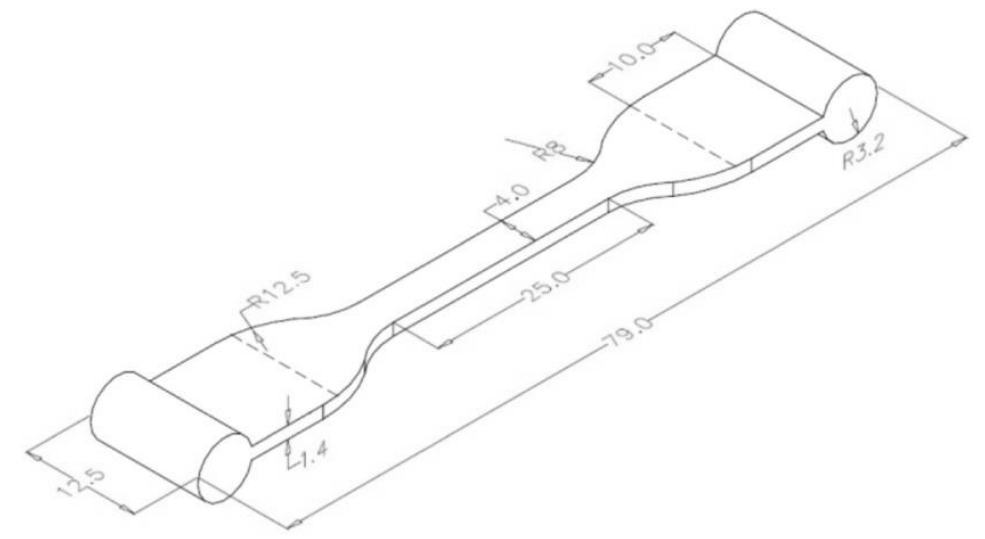

Şekil 5. Test numunesi (Liu ve Sancaktar, 2018).

\section{Araştırma Sonuçları ve Tartışma}

\section{1. Çekme Deneyi Sonuçları}

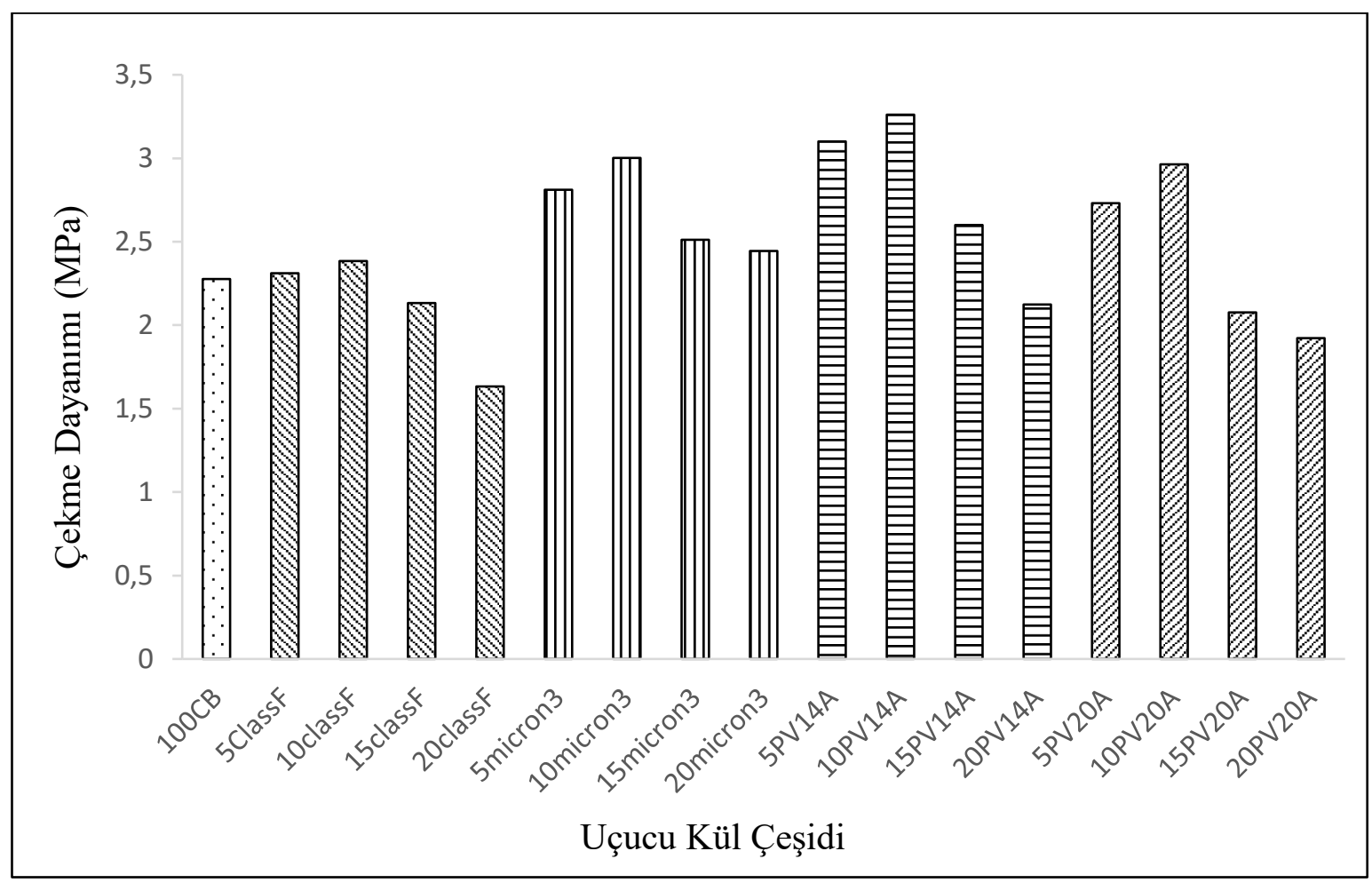

Şekil 6. Deney Numunelerinin Çekme Deneyi Sonuçları

Brabender Cihazında karıştırılan ve kürleştirilen numunelerin mekanik özelliklere etkisini anlamak için çekme deneyleri yapılmış ve farklı oranlara sahip uçucu küller ile karbon siyahı numuneleri karşılaştırılmıştır. Çekme deneylerinin tutarlılı̆̆ için test numuneleri farklı kalıplamalara ait 5 numuneden seçilerek deneyler yapılmıştır. Deneylerin sonuçlarına göre (Şekil 6) SBR kauçuğuna uçucu küller ikincil katkı maddesi olarak eklendiğinde kauçuğun çekme dayanımının arttığı görülmektedir. Şekil 6'ya göre PV 14A tipi uçucu kül eklenmiş kauçuğun çekme dayanımı ortalama \%20-25 oranında artmış, en fazla çekme dayanımı \%43 artış ile 
kauçuğa \%10 oranında PV 14A tipi uçucu kül eklendiğinde gözlenmiştir. Aynı şekilde Micron ${ }^{3}$ tipi uçucu kül ile birleştirilmiş kauçuğun çekme dayanımı ortalama \%15-20 oranında artmış, en fazla çekme dayanımı \%31,6 artış ile kauçuğa \%10 oranında Micron ${ }^{3}$ tipi uçucu kül eklendiğinde gözlenmiştir. PV 20A tipi uçucu kül ile birleştirilmiş kauçuğun çekme dayanımı ortalama \%8-10 oranında artmış, en fazla çekme dayanımı \%30 ile kauçuğa \%10 oranında PV 20A tipi uçucu kül eklendiğinde gözlenmiştir. Class F tipi uçucu kül ise kauçuğa \%10 oranında eklendiğinde \%0.44'lük bir çekme dayanımı artışı göstermiştir. Deney sonuçlarına göre kauçuğa ikincil katkı maddesi olarak uçucu kül eklendiğinde malzemenin çekme dayanımında artış gözlenmektedir. Çekme dayanımlarında en büyük artışlar \%43 ile kauçuğa \%10 oranında PV 14A tipi uçucu kül ve \%31,6 ile kauçuğa \%10 oranında Micron ${ }^{3}$ tipi uçucu kül

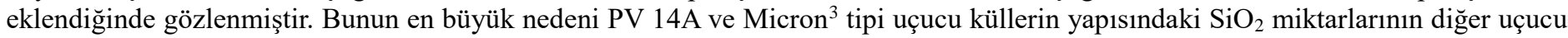
küllere oranla fazlalığıdır (Tablo 4).

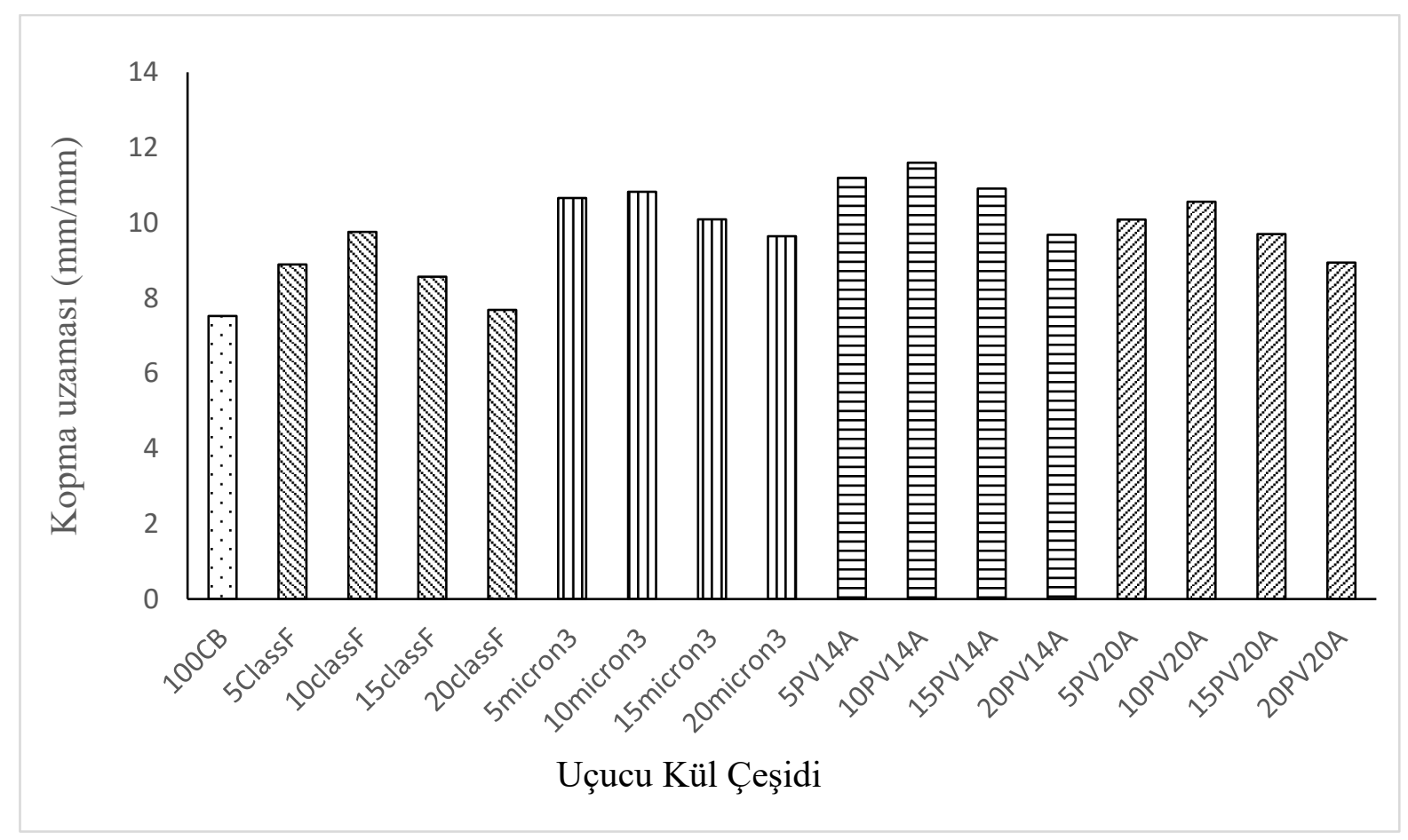

Şekil 7. Deney Numunelerinin kopma uzaması

Şekil 7'de kauçuğun ikincil katkı maddesi olarak farklı tiplerde uçucu kül ile birleştirilmesiyle oluşan numunelerin kopma uzaması dört farklı oran birlikte ele alınmıştır. SBR kauçuğunun PV14A uçucu kül eklenmesiyle oluşan numunelerin kopma uzaması ele alındığında, \%100 karbon siyahına oranla ortalama \%25-30 oranında artış göstermekte olup en fazla kopma uzaması \%54,3 ile \%10 oranında eklenen PV14A uçucu külde gözlenmiştir. Farklı oranlarda Micron ${ }^{3}$ tip uçucu kül eklenen kauçuk malzemenin kopma uzaması \%100 karbon siyahına oranla \%25-30 oranında artmış olup en fazla kopma uzaması fark1 \%43,8 ile \%10 oranında eklenen Micron $^{3}$ tipi uçucu külde gözlenmiştir. Kauçuğun PV 20A tipi uçucu kül ile birleştirilmesiyle oluşan numunelerin kopma uzaması dört farklı oran birlikte ele alındığında, kauçukla karbon siyahının \%100 olarak kullanıldığına oranla ortalama \%20-25 oranında artmış, en fazla kopma uzaması \%40,4 ile kauçuğa \%10 oranında PV 20A tipi uçucu külde gözlenmiştir. Class F tipi uçucu külün karbon siyahı ile kopma uzaması oranlamasında artış ortalama \%10-15 civarında olup en fazla fark \%29,8 oranında uçucu külde gözlenmiştir. Şekil 7'ye göre kauçuk malzemeye ikincil katkı maddesi olarak uçucu kül eklenmesi malzemenin kopma uzamasına önemli etkide katkı sağlamaktadır. 


\section{2. Çekme Deneyi Sonucu Fotoğrafları}

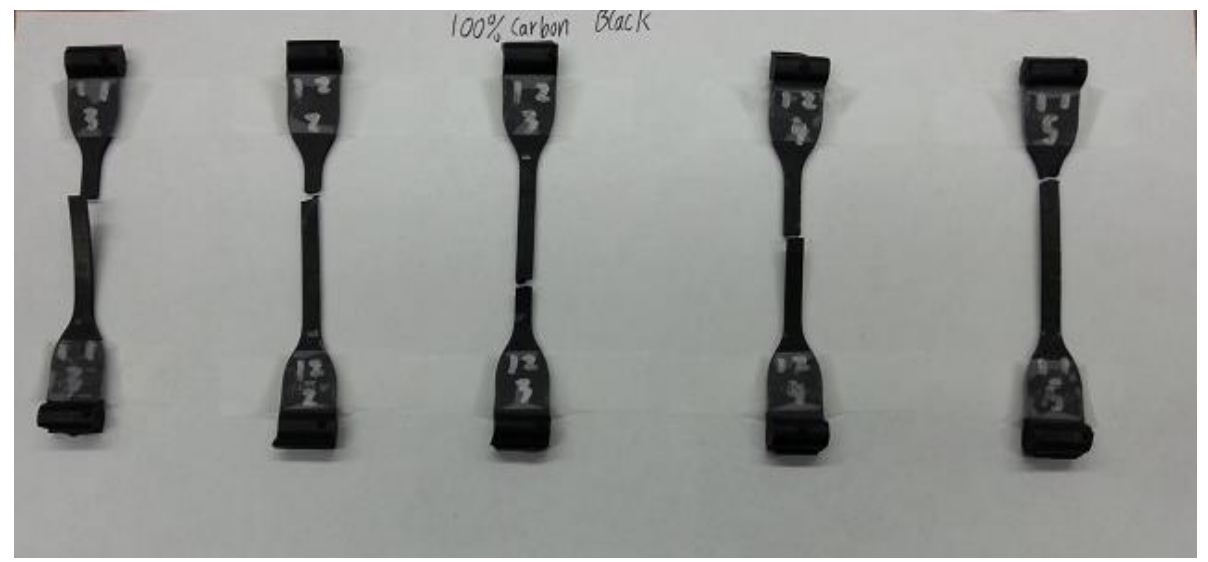

Şekil 8. \%100 Karbon Siyahı numunelerinin çekme deneyi sonrası fotoğrafları

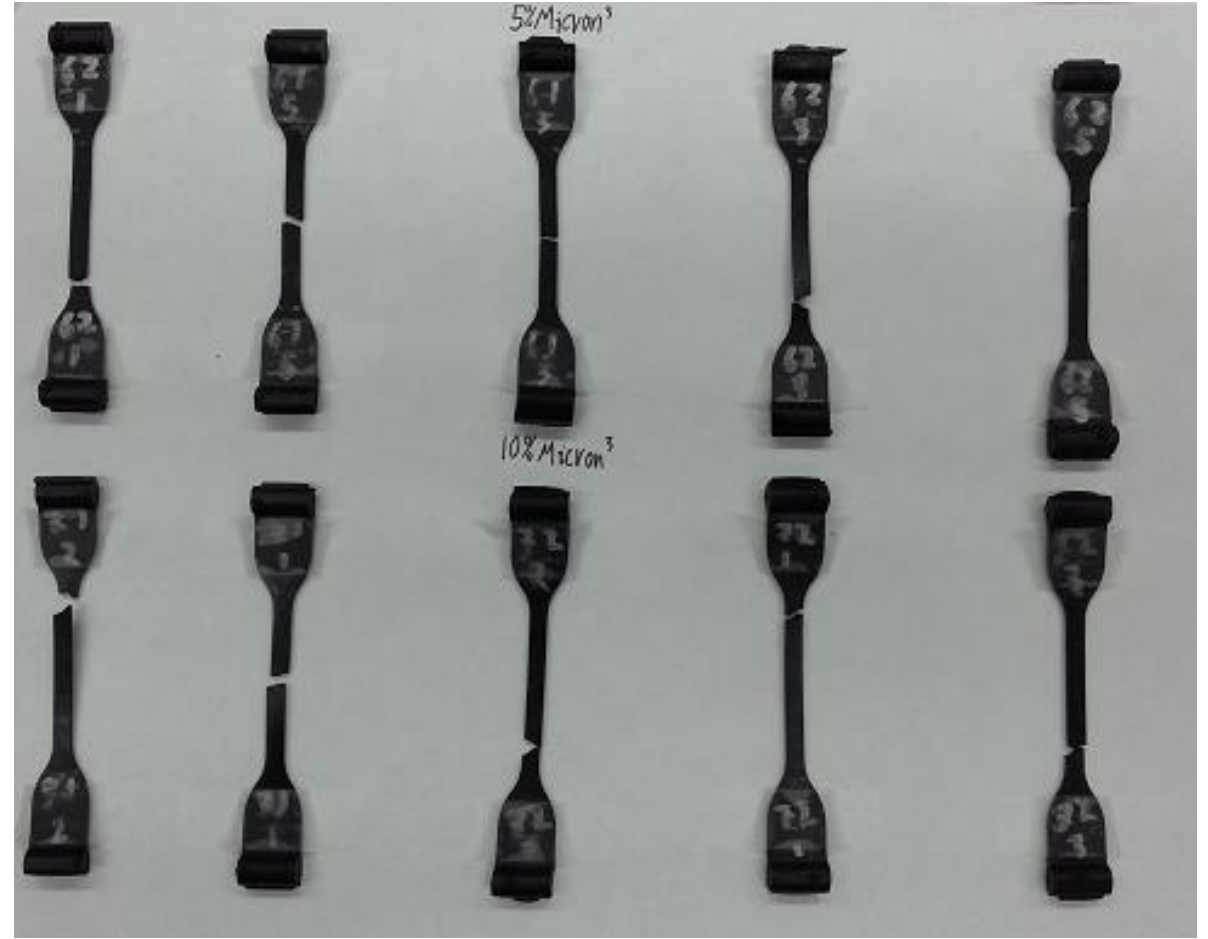

Şekil 9. \%5 ve \%10 Micron ${ }^{3}$ numunelerinin çekme deneyi sonrası fotoğrafları 
European Journal of Science and Technology

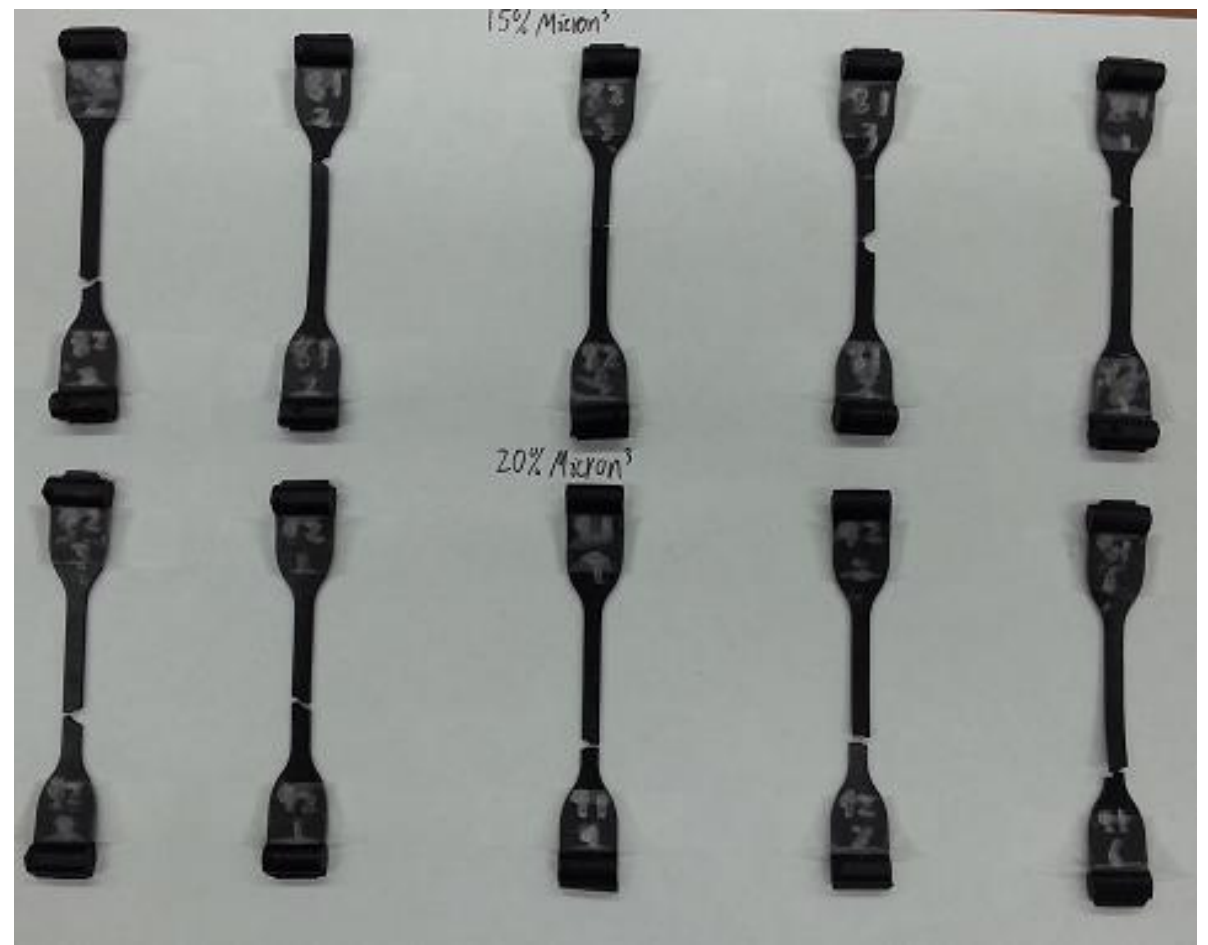

Şekil 10. \%15 ve \%20 Micron ${ }^{3}$ numunelerinin çekme deneyi sonrası fotoğrafları

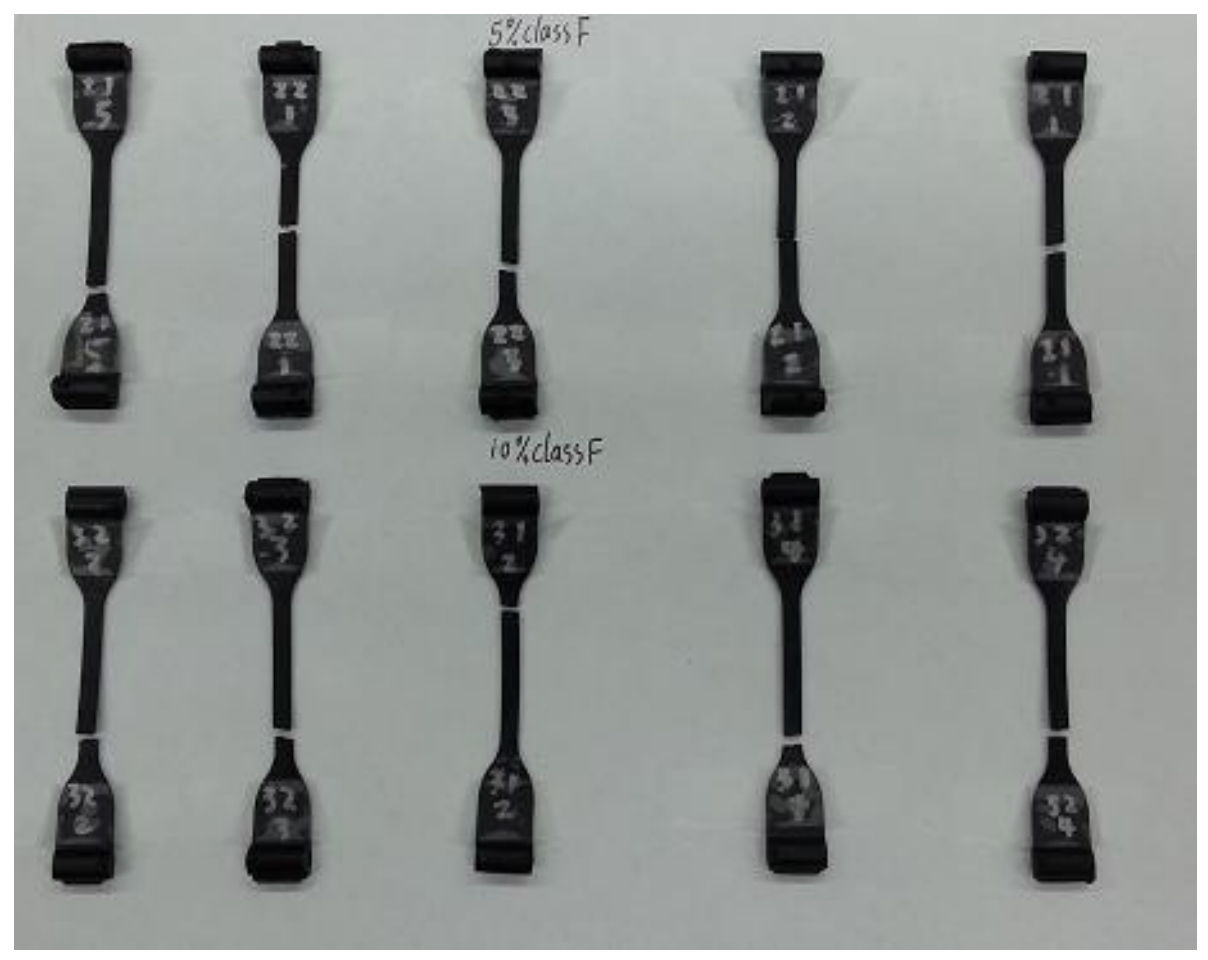

Şekil 11. \%5 ve \%10 Class F numunelerinin çekme deneyi sonrası fotoğrafları 


\section{Avrupa Bilim ve Teknoloji Dergisi}

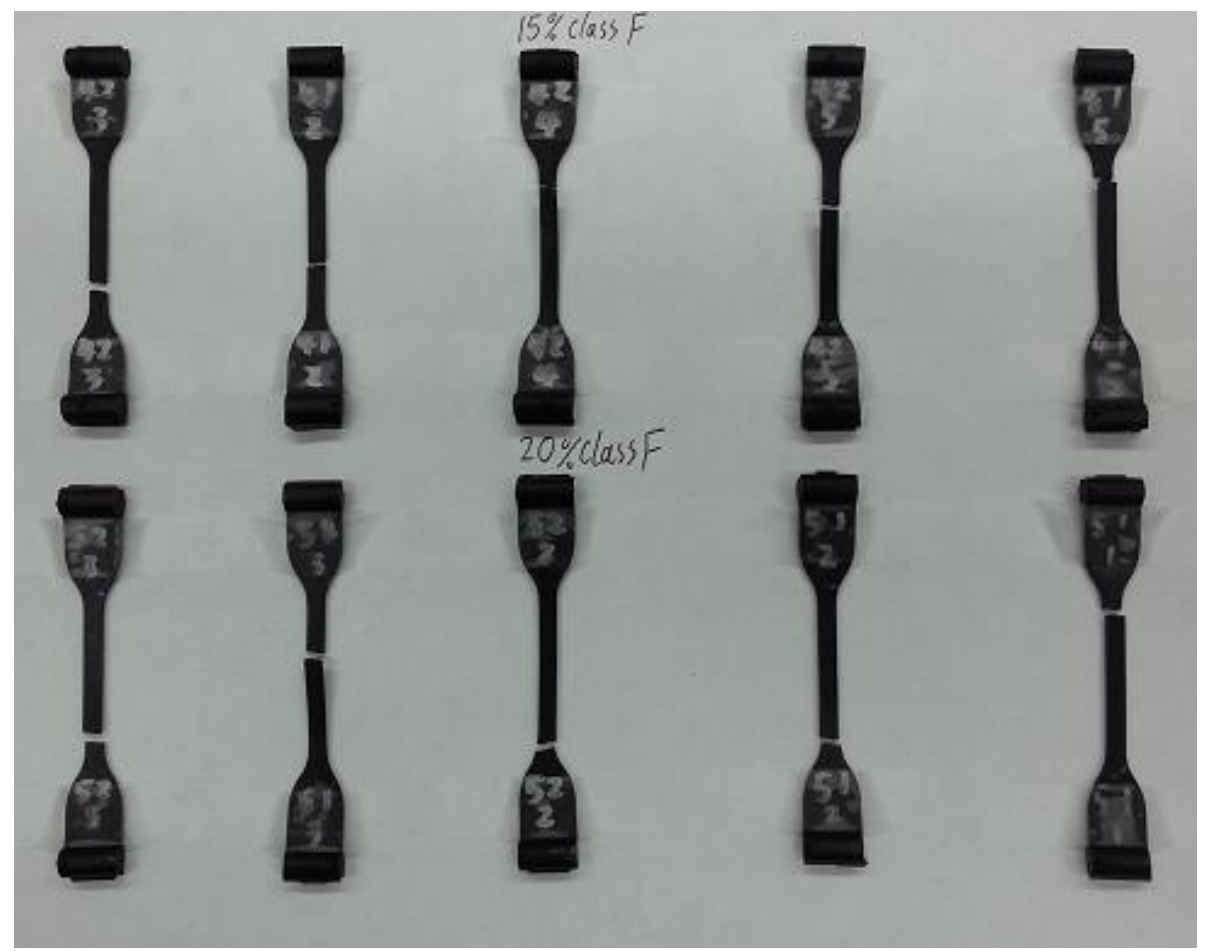

Şekil 12. \%15 ve \%20 Class F numunelerinin çekme deneyi sonrası fotoğrafları

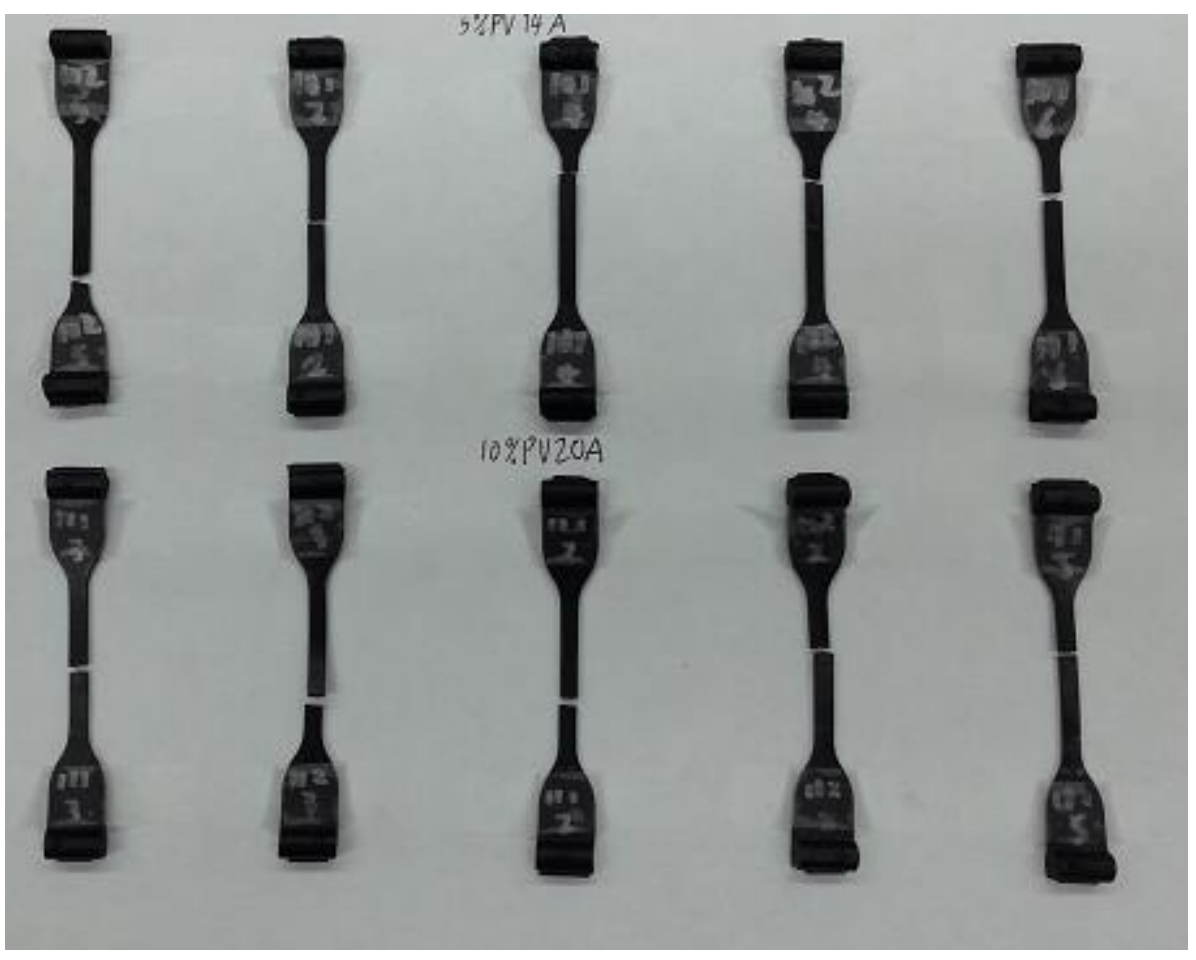

Şekil 13. \%5 ve \%10 PV 14 A numunelerinin çekme deneyi sonrası fotoğrafları 
European Journal of Science and Technology



Şekil 14. \%15 ve \%20 PV 14A numunelerinin çekme deneyi sonrası fotoğrafları

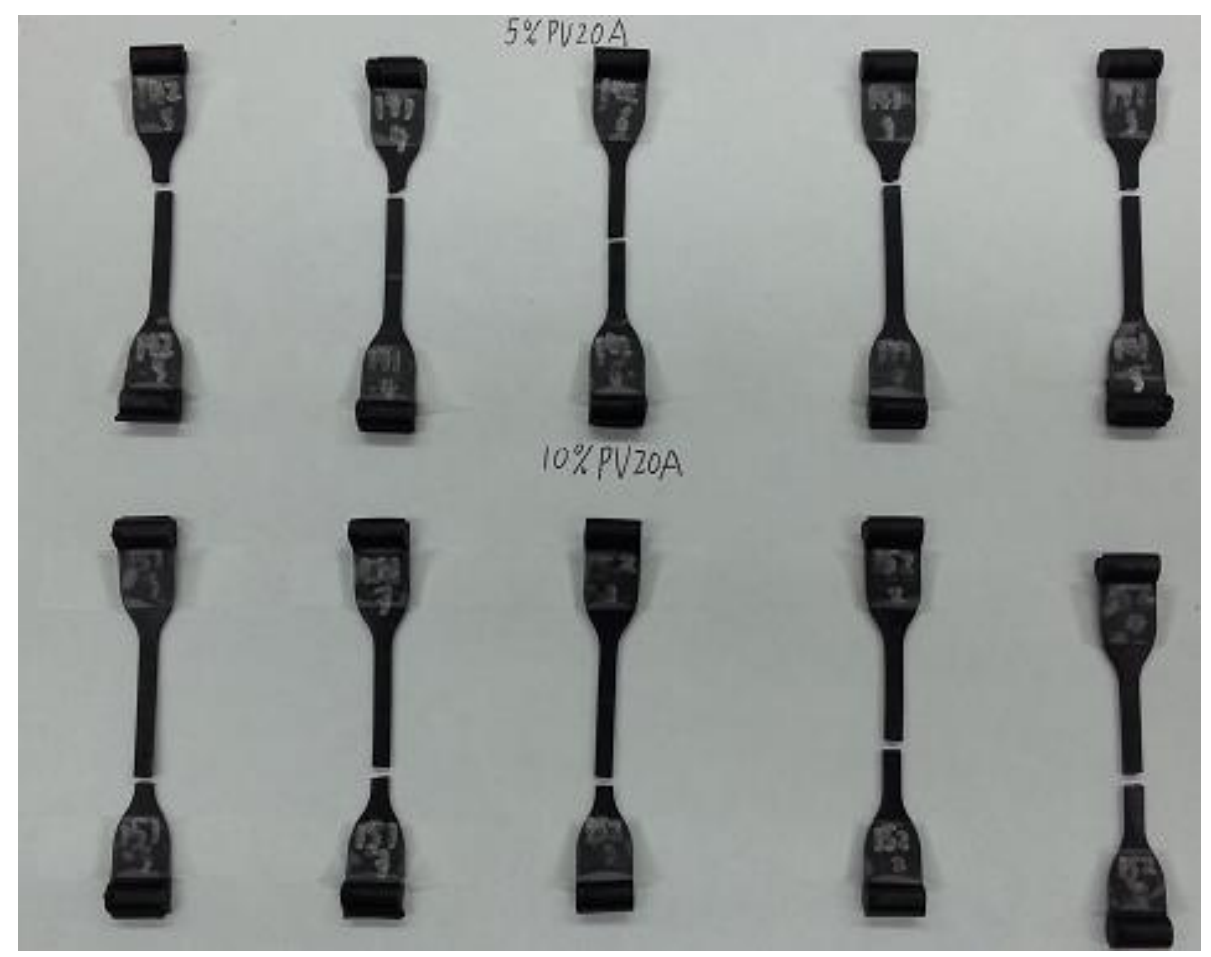

Şekil 15. \%5 ve \%10 PV 20A numunelerinin çekme deneyi sonrası fotoğrafları 


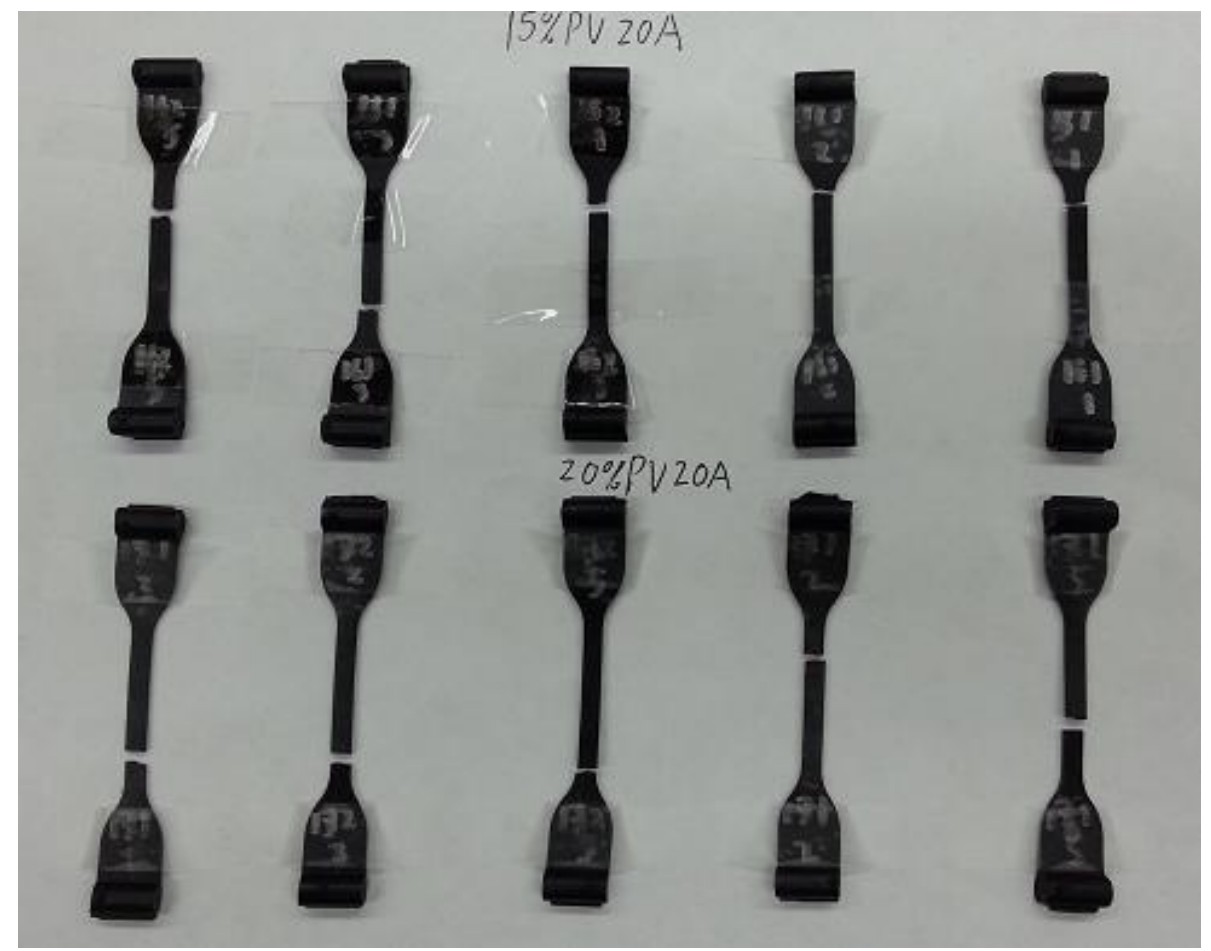

Şekil 16. \%15 ve \%20 PV 20A numunelerinin çekme deneyi sonrası fotoğrafları

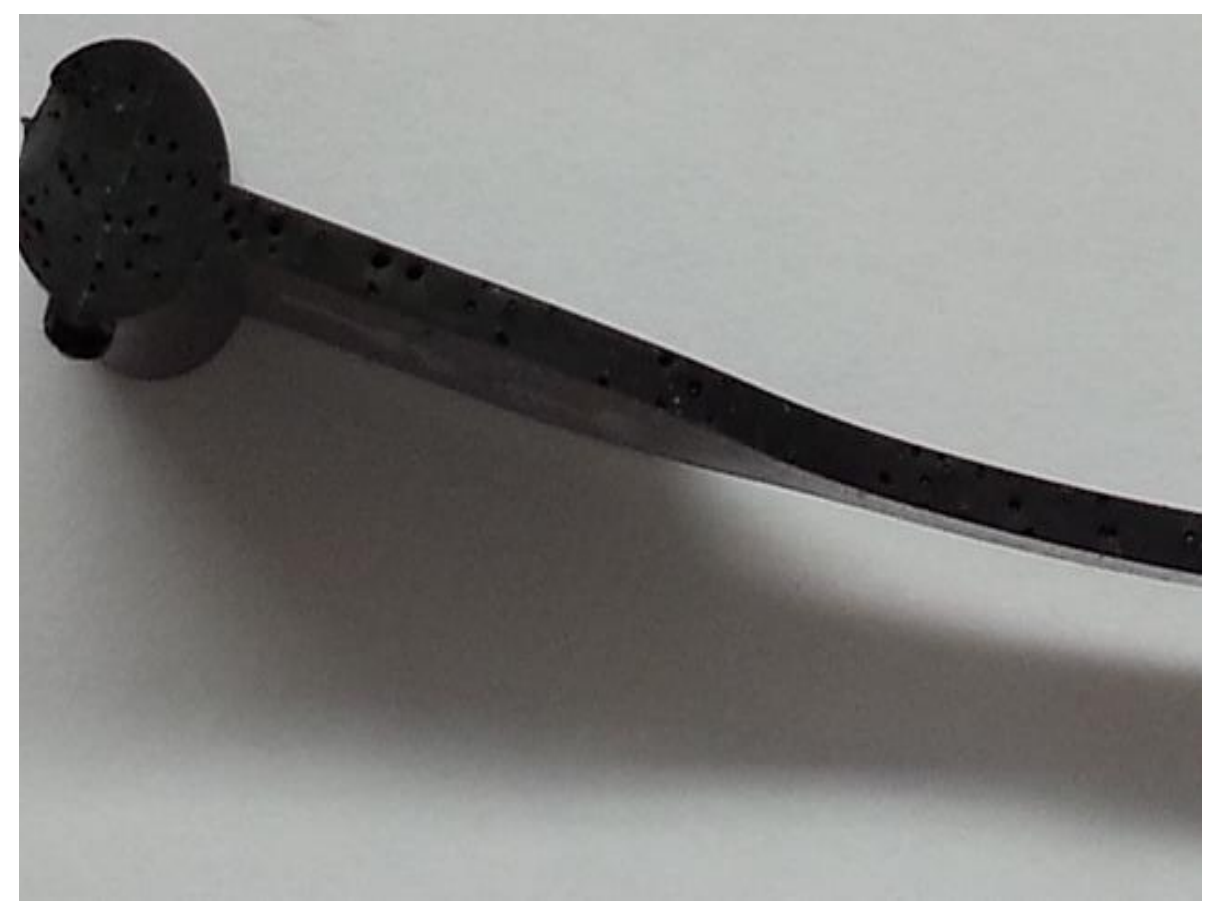

Şekil 17. \%100 uçucu kül ilave edilmiş SBR numunesi

Şekil 8 kauçuğa \%100 karbon siyahının birincil katkı maddesi olarak ilave edilmiş numunelerinin çekme deneyi sonrası fotoğraflarıdır. Şekil 9 ve 10 kauçuğa \%5-20 arası Micron ${ }^{3}$ tipi uçucu külünün ikincil katkı maddesi olarak ve \%80-95 arası karbon siyahının birincil katkı maddesi olarak ilave edilmiş numunelerinin çekme deneyi sonrası fotoğraflarıdır. Şekil 11 ve 12 kauçuğa \%520 arası Class F tipi uçucu külünün ikincil katkı maddesi olarak ve \%80-95 arası karbon siyahının birincil katkı maddesi olarak ilave edilmiş numunelerinin çekme deneyi sonrası fotoğraflarıdır. Şekil 13 ve 14 kauçuğa \%5-20 arası PV14A tipi uçucu külünün ikincil katkı maddesi olarak ve \%80-95 arası karbon siyahının birincil katkı maddesi olarak ilave edilmiş numunelerinin çekme deneyi sonrası fotoğraflarıdır. Şekil 15 ve 16 kauçuğa \%5-20 arası PV 20A tipi uçucu külünün ikincil katkı maddesi olarak ve \%80-95 arası karbon siyahının birincil katkı maddesi olarak ilave edilmiş numunelerinin çekme deneyi sonrası fotoğraflarıdır. Şekil 8-16 incelendiğinde, her bir uçucu kül çeşidi için 5 farklı çekme deneyinin yapıldığı ve bu deneylerin standartlara uygun olarak belirlenen bölgelerden koptuğu görülmektedir. 
Şekil 17 kauçuğa \%100 uçucu külün birincil katkı maddesi olarak ilave edilmiş numunenin çekme deneyi sonrası fotoğraflarıdır. Şekil 17 incelendiğinde numunenin üzerinde oluşan dairesel şekilli boşluklar kauçuğun mekanik özelliklerini zayıflatmakta, çekme dayanımı ve kopma uzaması değerlerini düşürmektedir.

\section{Sonuç}

Termik santrallerde kömürün yanması sonucu ortaya çıkan uçucu küllerin çevreyi olumsuz yönde etkilememesi için birçok çalı̧̧ma yapılmaktadır. Bu çalışmalardan bir tanesi de uçucu küllerin SBR (stiren bütadien kauçuk) ile birincil veya ikincil katkı maddesi olarak birleştirilmesidir. Hedeflenen amaç; uçucu küllerin çevresel atık olarak imhasının yanı sıra kauçuğun mekanik özelliklerinin iyileştirilmesidir. Bu amaçla ilk önce SBR ile kimyasal özellikleri birbirinden farklı 4 çeşit uçucu kül birincil katkı maddesi olarak karıştırılmıştır. Elde edilen numuneler günümüzde endüstride sıklıkla kullanılan birincil katkı maddesi sadece karbon siyahı olan SBR ile karşılaştırıldığında dört çeşit uçucu küle ait numunelerin hem çekme dayanımlarının hem de kopma uzamalarının düşük olduğu gözlenmiştir. Ayrıca içyapılar mikroskopta incelendiğinde test numunelerinde baloncuk adı verilen küçük dairesel boşlukların olduğu gözlenmiştir. Çekme testlerinde kopmaların dairesel boşlukların olduğu bölgelerde oluştuğu belirlenmiş̧ir. Bu boşlukları önlemek için SBR tipi kauçuk birincil katkı maddesi olarak karbon siyahı, ikincil katkı maddesi olarak 4 farklı uçucu kül ile dört farklı oranlarda karıştırılmıştır. Yapılan çekme deneyleri sonucunda uçucu küllerin kauçuğa \%5 oranında ikincil katkı maddesi olarak kullanıldığında çekme dayanımının ve kopma uzamasının artış gösterdiği, \%10 oranında ikincil katkı maddesi olarak kullanıldığında maksimum artışın olduğu gözlenmektedir. Buda Literatürde (Hamamcı, 1991; Ooi vd., 2013; Cokca ve Yilmaz, 2004; Ray, 2009 ) yapılan çalışmalarla uygunluk göstermektedir. Dört farklı uçucu kül kendi içerisinde karşılaştırılırsa PV 14A tipi uçucu külün \%10 oranında ikincil katkı maddesi olarak kullanıldığı kauçuk bileşiminde çekme dayanımı ve kopma uzaması maksimumdur. Bunun başlıca sebebinin bu tip uçucu külün içerisindeki Si miktarı diğer tip uçucu küllere oranla daha fazla olduğu söylenebilir.

Termik santrallerde kömürün yanması sonucu ortaya çıkan uçucu küller ile ilgili yapılan çalışmalar son yıllarda gittikçe hız kazanmaktadır. Bu çalışmalardan bir tanesi de uçucu küllerin SBR (stiren bütadien kauçuk) ile birincil veya ikincil katkı maddesi olarak birleştirilmesidir. Uçucu küller ile ilgili yapılabilecek diğer çalışmalar ise; Si-69 yöntemiyle uçucu küllerin yapısındaki silis miktarını arttırma ve mikrodalga yöntemiyle tanecik boyutunu küçültme şeklindedir.

\section{Teșekkür}

Bu çalışma Hitit Üniversitesi Bilimsel Araştırma Projesi MUH19006.13.001 ile desteklenmiştir. Çalışmalar Akron Üniversitesi (ABD) Polimer Mühendisliği Bölümü Laboratuvarlarında yapılmıştır. Bu çalışmada katkılarından ve desteklerinden dolayı Prof. Dr. Erol SANCAKTAR'a teşekkür ederim.

\section{Kaynakça}

Alataş, T. (1996). Afşin Elbistan Termik Santrali uçucu külünün yol stabilizasyonunda çeşitli maddelerle birlikte kullanımı üzerinde bir araştırma. Doktora Tezi. Fırat Üniversitesi/Fen Bilimleri Enstitüsü.

Bahruddin, A., Ahmad, A., Prayitno, A., Satot, R. (2012). Morphology and mechanical properties of plam based fly ash reinforced dynamically vulcanized natural rubber/polypropylene blends. Procedia Chemistry, 4, 146-153.

BORAL

http://www.boralna.com/brochures/ordering/default.asp?site=boral_na \&company=Fly\%20Ash\&product=Flyash\&category=443\&c_name=MSDS\%20Sheets\&scr=1. Erişim tarihi: 14 Ocak 2020.

Büyüköner, B. (1989). Properties of compacted and steam cured fly ash lime masonryunits. Yüksek Lisans Tezi. ODTÜ/Fen Bilimleri Enstitüsü.

Cokca, E., Yilmaz, Z. (2004). Use of rubber and bentonite added fly ash as a liner Material. Waste Management, 24, 153-164.

Elverici, Ü. (1986). Effect of blast furnace slag and flyash on the stabilization of base materials. Yüksek Lisans Tezi. ODTÜ/Fen Bilimleri Enstitüsü.

Ergüt, Ş. (1994). Seyitömer Termik Santral atık uçucu küllerinin sinterleşme karakterizasyonu. Yüksek Lisans Tezi. İTÜ/Fen Bilimleri Enstitüsü.

Feldman, D. (2012). Elastomer nanocomposites; Properties. Journal of Macromolecular Science, Part A:Pure and Applied Chemistry, 49, 784-793.

Garde, K., McGill, W., J., Woolard, C., D. (1999). Surface modification of fly ash-characterisation and evaluation as reinforcing filler in polyisoprene. Plastics, Rubber and Composites, 28, 1-10.

Güler, G., Güler, E., İpekoğlu, U., Mordoğan, H. (2005). Uçucu küllerin özellikleri ve kullanım alanları. IMTEC2005, 419-423.

Hamamc1, R. B. (1991). Effect of rubber, carbon black and fly ash on physical properties of pavements. Yüksek Lisans Tezi. Boğaziçi Üniversitesi/Fen Bilimleri Enstitüsü.

Kanking, S., Niltui, P., Wimolmala, E., Sombatsompop, N. (2012). Use of bagasse fiber ash as secondary filler in silica or carbon black filled natural rubber compound. Materials and Design, 41, 74-82.

LANXESS, (2019). https://techcenter.lanxess.com/pbr/emea/en/products/datasheet/ Buna _ VSL_ $\quad 5025-2 \quad$ HM.pdf?docId=7960864\&gid=1807\&pid=10. Erişim tarihi: 14 Ocak 2020.

Liu, R., Sancaktar, E. (2018). Durability assessment via residul strength and viscoelastic observations on filled rubber compounds. Fatigue \& Fracture of Engineering Materials \& Structures, 41-9, 2054-2065.

Morrison, R. E. (1970). A review of ash specifications. Symposium of Fly Ash Utilization, 24-31. 
Ooi, X. Z., Ismail, H., Bakar, A. A. (2013). Synergistic effect of palm ash filled rubber compound at low filler loading. Polymer Testing, 32, 38-44.

Paul, K., T., Pabi, S., K., Chakraborty, K., K., Nando, G., B. (2009). Nanostructured fly-ash styrene butadiene rubber hybrid nanocomposites. Polymer Composites, 1647-1656.

Rattanasom, N., Saowapark, T., Deeprasertkul, C. (2007). Reinforcement of natural rubber with silica/carbon black hybrid filler. Polymer Testing, 26, 369-377.

Ray, D. (2009). Modification of the dynamic damping behavior of fly ash filled unsaturated polyester resin/SBR latex blend composites. Journal of Reinforced Plastics and Composites, 28, 1537-1552.

Savran, K. Z. (1988). Stabilization of cohesive soils with fly ash. Yüksek Lisans Tezi. ODTÜ/Fen Bilimleri Enstitüsü.

Sombatsompop, N., Thongsang, S., Markpin, T., Wimolmala, E. (2004). Fly ash particles and precipitated silica as fillers in rubbers. I. Untreated fillers in natural rubber and styrene-butadiene rubber compounds. Journal of Applied Polymer Science, 93, 2119-2130.

Toros, H. (1987). Afşin Elbistan Termik Santrali uçucu küllerinin yapı malzemesi olarak kullanılması. Yüksek Lisans Tezi. ITÜ/Fen Bilimleri Enstitüsü.

Uysal, F. (1987). Geotechnical Properties of the fly-ashes produced in to thermal plants in Turkey. Yüksek Lisans Tezi. ODTÜ/Fen Bilimleri Enstitüsü.

Van der Merwe, E., M., Prinsloo, L., C., Mathebula, C., L., Swart, H., C., Coetsee, E., Doucet, F., J. (2014). Surface and bulk characterization of an ultrafine South African coal fly ash with reference to polymer applications. Applied Surface Science, 317, 73-82.

Wasti, Y. (1990). Uçucu küllerin geoteknik özellikleri ve kullanım olanakları. IMO Teknik Dergi, 1, 177-188.

Yılmaz, Ş. (1982). Seyitömer Termik Santral atık uçucu küllerinin yapı malzemesi olarak değerlendirilmesi. Yüksek Lisans Tezi. ODTÜ/Fen Bilimleri Enstitüsü. 